\title{
ANALYSIS OF MARKETING STRATEGY FOR MOBILE VEGETABLE TRADERS IN SUKORAMBI DISTRICT JEMBER REGENCY
}

\author{
Ahmad Sauqi ${ }^{1}$ \\ Higher Education of Economic Mandala \\ Email: sauqi@stie-mandala.ac.id
}

\begin{abstract}
In Sukorambi District, many of the people are engaged in the mobile vegetable trading business. The sampling technique uses a multistage sampling technique, the SWOT analysis method by determining the IFAS Matrix, EFAS. From the results of IFAS the strength and weakness factors have a total score of 2.95. Value> 2.5 indicates a strong internal potential. From this it can be judged that the internal potential of the mobile vegetable traders is strong. From the EFAS results, the opportunity and threat factors have a score of 3.59. Because the total score is close to 4.0 , it means that this indicates that the mobile vegetable traders respond to the opportunities in an extraordinary way. SO strategy by maintaining the quality of the product being sold. ST strategy by providing the maximum possible service. WO strategy by starting the use of price tagging. WT strategy by improving the quality of packing.
\end{abstract}

Keywords: Strategy; Marketing; Traders; Vegetable Around.

\section{INTRODUCTION}

In the era of the industrial revolution 4.0, people around the world are increasingly spoiled with various conveniences in living their lives, starting from the fields of transportation, communication, commerce and so on.Various sophistication of facilities and infrastructure in supporting life activities are the thoughts of creative humans who have been given reason by Allah SWT. We all know that Rosulullah has said that 9 out of 10 doors of sustenance are in trade, on this basis marketing activities are actually very important activities because smooth marketing of products or services will generate benefits for both individuals who work or groups and even companies. Marketing currently tends to lead to an online system by utilizing information technology in an applicable way, for example by using the Facebook application which is famous for its Market Placenya, Tokopedia, Shopee and so on.

The Industrial Revolution 4.0, which is always buzzing around in various scientific activities, even in various electronic and print media, of course, we have to face it with openness, including in terms of increasingly fierce competition over the various easiness of buying and selling support using applications and other social media. Nowadays, there are more and more people who open shops, both 
grocery, clothing, household goods and so on. The point is that the imbalance between population density and needs in the world of work will encourage people to be innovative in opening their own business, but the problem is that businesses that are easy to imitate tend to have many competitors. Sukorambi Subdistrict is a sub-district that is arguably very close to Jember City Square, the people are still very many who make a living as farmers, especially vegetable farmers. There is a business phenomenon in this sub-district where many of the people are involved in the mobile vegetable trading business using motorbikes. In addition to the above business phenomena, there is currently very tight competition between vegetable traders from the Sukorambi sub-district. Their marketing area, which is usually carried out in densely populated areas, for example in housing, has a large number of other vegetable traders who are also competing for their fortune in selling areas.

Based on information from several mobile vegetable traders from Sukorambi sub-district that the researchers met several months ago, they stated that the competition they face has an impact on the sales they earn every day, meaning that profits are increasingly erratic and very different from the previous time. ie 5 or 3 years ago. They also conveyed that the mobile vegetable trading business has also been in demand by the younger generation, both men and women, meaning that the vegetable traders are still young and some have just graduated from junior high or high school. Based on the business phenomena and the discussion that has been written previously, I as a researcher is motivated to explore more about the business activities of mobile vegetable traders, more in their marketing strategy with the 4P approach, namely Price, Product, Place and Promotion using SWOT analysis.

Referring to the discussion of the background of the problem above, the researcher formulates the problem formulation as follows. What are the marketing strategies from the point of view of Price, Product, Place and Promotion and alternative marketing strategies that can be implemented in mobile vegetable traders in Sukorambi District, Jember Regency. Research purposes, Knowing marketing strategies from the point of view of Price, Product, Place and Promotion as well as alternative marketing strategies that can be implemented in mobile vegetable traders in Sukorambi District, Jember Regency.

Before defining the mobile vegetable trader, we will be more specific, we will focus more on the wording of the mobile vegetable trader. First, according to (Todaro: 2000) a trader is a person who trades and sells goods that are not produced by himself to obtain a profit. Vegetables are leaves (such as mustard greens), plants (bean sprouts), legumes (peas, beans) and so on, which can be cooked (KBBI Online: 2020). Traveling is the neighborhood (KBBI Online: 2020). From the meaning starting from traders, vegetables and traveling, if we combine and summarize, the meaning of a traveling vegetable trader is a person who carries out activities of buying and selling leaves such as mustard greens, bean sprouts and so on, which essentially can be cooked with the aim of seeking profit in the form of delivery activities. merchandise into the hands of direct consumers who become their marketing targets.

Marketing strategy is a series of goals and objectives, policies and rules that give direction to the company's marketing efforts from time to time, at each level and its references and allocations, especially as a company's response to the ever-changing competitive environment and conditions. (Sofjan: 2013). The product marketing mix consists of the 4Ps, namely product, price, place and promotion (Kotler: 2013). A product is anything that can be offered to the market to satisfy their wants or needs as consumers. Products marketed include 
physical goods, experiences, events, people, places, and ideas. Buyers buy products because of the value that they contain

\section{RESEARCH METHODS}

The research with the title Analysis of Mobile Vegetable Trader Marketing Strategies in Sukorambi Jember District was carried out for 3 months, namely the beginning of July 2020 to the end of September 2020. This research was conducted in the Sukorambi Jember District area to be precise in 3 villages namely Sukorambi, Karangpring and Klungkung Villages. with the consideration of these three villages, many of the people work as mobile vegetable traders.

Primary data and secondary data are used in this study, the population in this study were all mobile vegetable traders in Sukorambi District, Jember Regency. The samples in this study were 45 mobile vegetable traders in Sukorambi District, Jember Regency.

The sampling technique in this study was using multistage sampling technique with a total sample of 45 mobile vegetable traders as respondents. The main centers of mobile vegetable traders in Sukorambi District, Jember Regency are Sukorambi, Karangpring and Klungkung Villages (BPS, 2020). Of the 5 villages in Sukorambi Jember District, 3 villages were taken namely Sukorambi, Karangpring and Klungkung villages. From each village, 15 mobile vegetable traders were taken as respondents so that the total number of respondents was 45 people.

Methods of data analysis using SWOT with identification of various factors systematically to formulate corporate strategy. This analysis is based on the logic to formulate strength (strength) and opportunity (opportunity), but at the same time minimizing weakness (weakness) and threats (treatment) are the factors of the company's strategy that must be analyzed in the current conditions
(Rangkuti: 2003). The strategic decisionmaking process will always be related to the development of the company's mission, goals, strategies and policies. Thus, strategic planning (strategic planner) must analyze the company's strategic factors (strengths, weaknesses, opportunities and threats) in the current conditions. Next will be calculated using the EFE Matrix (External Factor Evaluation), IFE Matrix (Internal Factor Evaluation), IFAS Matrix (Internal Analysis Summary), EFAS Matrix (External Factor Analysis Summary) and SWOT Matrix.

The SWOT matrix is a tool used to measure the factors of a company's strategy. This matrix can clearly describe how the external opportunities and threats are. SO strategy is a combination of internal factors (Strength) and external factors (Opportunity), this strategy is made based on the thoughts of company executives, namely by utilizing all strengths to seize and take advantage of opportunities as much as possible. ST strategy is a combination of internal factors (Strength) and external factors (Threat), this strategy uses the strength of a company to overcome all external threats. WO strategy is a combination of internal factors (Weakness) and external factors (Opportunity), this strategy is implemented based on the use of existing opportunities by reducing the weaknesses of the company. WT strategy is a combination of internal factors (Weakness) and external factors (Threat), this strategy is also based on defenisive activities and tries to avoid all possible external threats to reduce the weaknesses of the company being run.

\section{RESULT ANALYSIS}

Internal Environmental Analysis. (Strength) 1.Vegetables are sold in a wide variety. 2.The vegetables sold are of high quality (still fresh). 3.Serve buyers well. 4.Provide discounts for loyal customers. 5. Provide annual bonuses for loyal customers. 6.On certain days often carry out promotions, for example buying 4 
packs of vegetables, 1 pack free. (Weakness) 1.Self-packaged vegetables sometimes use banana leaf wrappers. 2.Never give price labels to vegetables being sold, relying on memory alone. 3. Often provide debts to buyers even though they are at risk of not being paid.

External Environmental Analysis. (Opportunity) 1.Often advertise products sold through the Facebook marketplace when the price of certain vegetables goes up. 2.Traders always maintain good relations with customers, for example by being friendly. 3. Providing offers through social media in the form of Whatsapp, merchants send WA to certain customers who are accustomed to placing orders beforehand. 4.The handle feels easy in getting merchandise. (Threat) 1.Tight competition (the proliferation of mobile vegetable traders). 2. The home of the mobile vegetable traders is far from the location where they sell their products, so they have to hunt for time each day so that customers do not move or buy from other traders. 3.Customers who are decreasing from time to time since the increasing number of vegetable traders around.

Table 1. Data Matriks IFAS (Internal Factor Analysis Summary)

\begin{tabular}{|c|c|c|c|c|}
\hline \multirow[t]{2}{*}{ Number } & Internal Factor & \multirow[b]{2}{*}{ weight } & \multirow[b]{2}{*}{ Rating } & \multirow[b]{2}{*}{ Score } \\
\hline & (Strenght) & & & \\
\hline 1. & Vegetables are sold in a wide variety & 0,13 & 4 & 0,52 \\
\hline 2. & The vegetables sold are of high quality (still fresh). & 0,12 & 3 & 0,36 \\
\hline 3. & Serve buyers well. & 0,10 & 3 & 0,3 \\
\hline 4. & Provide discounts for loyal customers. & 0,10 & 3 & 0,3 \\
\hline 5. & Provide annual bonus for loyal customers. & 0,09 & 4 & 0,36 \\
\hline \multirow[t]{3}{*}{6.} & $\begin{array}{l}\text { On certain days, they often carry out promotions, for } \\
\text { example buying } 4 \text { packs of vegetables, } 1 \text { pack free. }\end{array}$ & 0,10 & 4 & 0,4 \\
\hline & Sub-total & $\mathbf{0 , 6 4}$ & & 2,24 \\
\hline & (Weakness) & & & \\
\hline 1. & $\begin{array}{l}\text { The self-packed vegetable packaging sometimes uses } \\
\text { banana leaf wrappers. }\end{array}$ & 0,13 & 1 & 0,13 \\
\hline 2. & $\begin{array}{l}\text { Never put a price tag on vegetables being sold, relying on } \\
\text { memory alone. }\end{array}$ & 0,11 & 2 & 0,22 \\
\hline \multirow[t]{3}{*}{3.} & $\begin{array}{l}\text { Often provides debts to buyers even though they are at risk } \\
\text { of not being paid. }\end{array}$ & 0,12 & 3 & 0,36 \\
\hline & Sub-total & $\mathbf{0 , 3 6}$ & & $\mathbf{0 , 7 1}$ \\
\hline & Total & 1 & & 2,95 \\
\hline
\end{tabular}

Data Processed : 2020

From the analysis in table 4.1 IFAS, the strength and weakness factors have a total score of 2.95. If the total score is below 2.5 it indicates that the trader is weak internally. Meanwhile, a total value above 2.5 indicates a strong internal potential. From this it can be judged that the internal potential of mobile vegetable traders in the Sukorambi Jember subdistrict is strong.

Table 2. Data Matriks Matrik EFAS (Eksternal Factor Analysis Summary)

\begin{tabular}{|c|c|c|c|c|}
\hline \multirow[t]{2}{*}{ Number } & Eksternal Factor & \multirow[b]{2}{*}{ Weight } & \multirow[b]{2}{*}{ Rating } & \multirow[b]{2}{*}{ Score } \\
\hline & (Opportunity) & & & \\
\hline 1. & $\begin{array}{l}\text { Often advertise products sold through the marketplace on } \\
\text { Facebook when the price of certain vegetables goes up. }\end{array}$ & 0,14 & 4 & 0,56 \\
\hline 2. & $\begin{array}{l}\text { Traders always maintain good relations with customers, for } \\
\text { example by being friendly. }\end{array}$ & 0,18 & 4 & 0,72 \\
\hline 3. & $\begin{array}{l}\text { Providing offers via social media in the form of Whatsapp, } \\
\text { merchants send WA to certain customers who are used to making } \\
\text { previous orders. }\end{array}$ & 0,15 & 4 & 0,6 \\
\hline
\end{tabular}




\begin{tabular}{|c|c|c|c|c|}
\hline \multirow[t]{2}{*}{ Number } & Eksternal Factor & \multirow[b]{2}{*}{ Weight } & \multirow[b]{2}{*}{ Rating } & \multirow[b]{2}{*}{ Score } \\
\hline & (Opportunity) & & & \\
\hline \multirow[t]{3}{*}{4.} & The handle finds it easy in getting merchandise. & 0,10 & 3 & 0,3 \\
\hline & Sub-total & $\mathbf{0 , 5 7}$ & & 2,18 \\
\hline & (Threat) & & & \\
\hline 1. & Tight competition (the proliferation of mobile vegetable traders) & 0,12 & 4 & 0,48 \\
\hline 2. & $\begin{array}{l}\text { The location of the mobile vegetable merchant's house is far from } \\
\text { the location where they sell, so they have to hunt for time each } \\
\text { day so that customers do not move or buy from other traders. }\end{array}$ & 0,15 & 3 & 0,45 \\
\hline \multirow[t]{3}{*}{3.} & $\begin{array}{l}\text { The number of customers has decreased from time to time since } \\
\text { the increasing number of mobile vegetable traders. }\end{array}$ & 0,16 & 3 & 0,48 \\
\hline & Sub-total & $\mathbf{0 , 4 3}$ & & $\mathbf{1 , 4 1}$ \\
\hline & Total & 1 & & 3,59 \\
\hline
\end{tabular}

Data Processed : 2020

From the results of the analysis in table 4.2 EFAS, the opportunity and threat factors have a score of 3.59. Because the total score is close to 4.0 , this means that it indicates that mobile vegetable traders in the Sukorambi Jember sub-district respond to opportunities in an extraordinary way and avoid threats in the market or where they are selling.

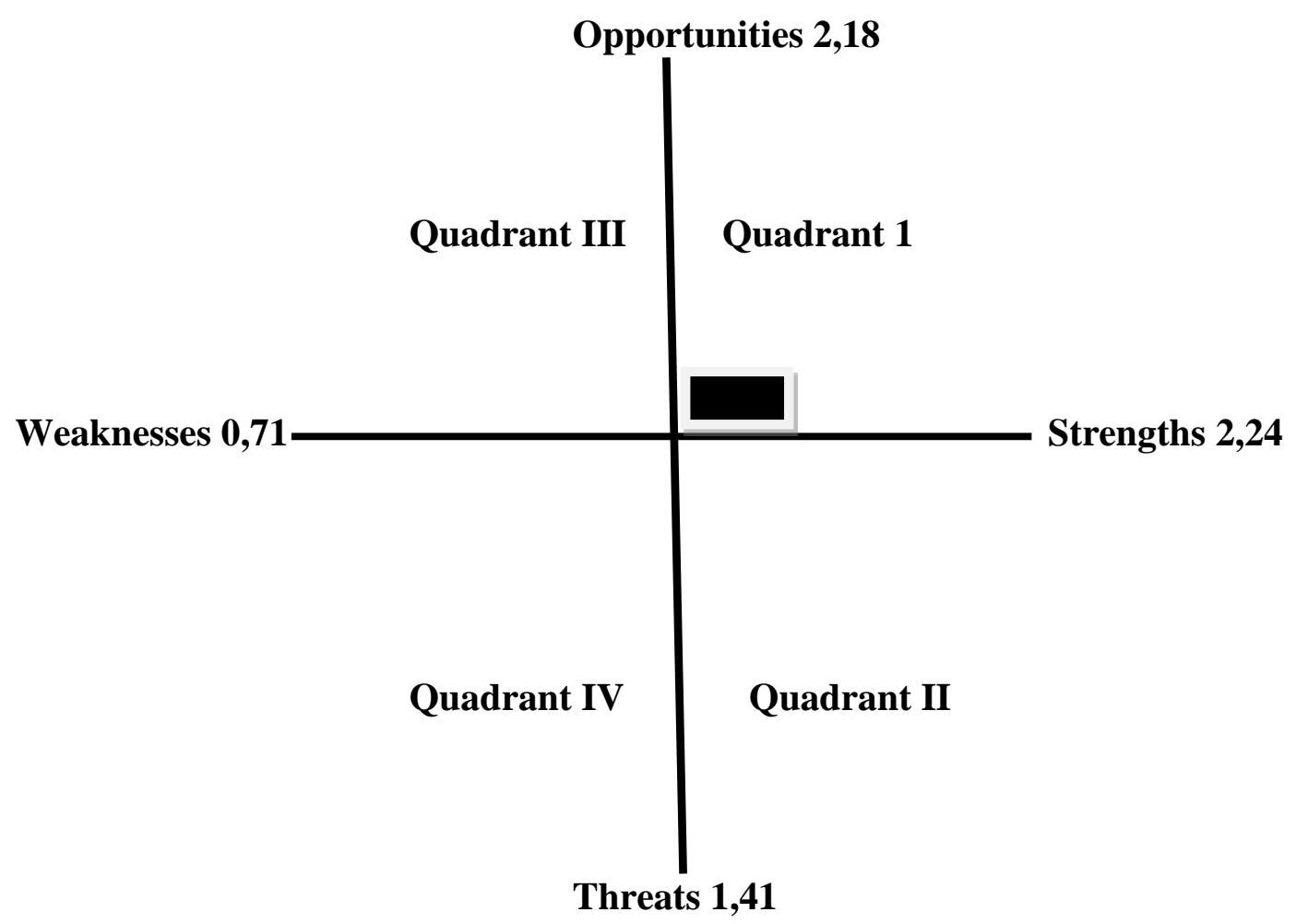

Figure 1. Cartesian Diagram SWOT Analysis of Mobile Vegetable Traders in Sukorambi District

The total value of Strength is 2.24, skill 0.71 , opportunity 2.18 , threat 1.41 . For the difference in the total score the factor is (Strength 2.24 - wekness 0.71) / $2=0.77$ this also applies to (opportunity 2.18 threat 1.41) / $2=0.39$. The following is the cartesian salt of SWOT analysis of mobile vegetable traders in the Sukorambi Jember district.

Based on the picture above, it can be explained that the mobile vegetable traders in Sukorambi Jember District are in 
quadrant I, namely Aggressive (Growth Oriented Strategy) where this power is a very profitable situation. These traders have opportunities and strengths so they can take advantage of the opportunities that exist.
This strategy that must be implemented in this condition is to support aggressive growth policies.

Table 3. Matriks SWOT

\begin{tabular}{|c|c|c|}
\hline & Strenght & Weakness \\
\hline & $\begin{array}{l}\text { 1. Vegetables are sold in a wide } \\
\text { variety. } \\
\text { 2. Vegetables that are sold are of } \\
\text { high quality (still fresh). } \\
\text { 3. Serve buyers well. } \\
\text { 4. Provide discounts for loyal } \\
\text { customers. } \\
\text { 5. Provide annual bonuses for } \\
\text { loyal customers. } \\
\text { 6. On certain days often carry out } \\
\text { promotions, for example buying } 4 \\
\text { packs of vegetables, } 1 \text { pack free. }\end{array}$ & $\begin{array}{l}\text { 1.Self-packaged vegetables } \\
\text { sometimes use banana leaf } \\
\text { wrappers. } \\
\text { 2. Never give price labels to } \\
\text { vegetables being sold, relying } \\
\text { on memory alone. } \\
\text { 3. Often provide debts to buyers } \\
\text { even though they are at risk of } \\
\text { not being paid. }\end{array}$ \\
\hline Opportunity & STRATEGY SO & STRATEGY WO \\
\hline $\begin{array}{l}\text { 1. Often advertise products sold } \\
\text { through the Facebook } \\
\text { marketplace when the price of } \\
\text { certain vegetables goes up. } \\
\text { 2. Traders always maintain good } \\
\text { relations with customers, for } \\
\text { example by being friendly. } \\
\text { 3. Providing offers via social } \\
\text { media in the form of Whatsapp, } \\
\text { merchants send WA to certain } \\
\text { customers who are accustomed to } \\
\text { making previous orders. } \\
\text { 4. The handle feels easy in } \\
\text { getting merchandise. }\end{array}$ & $\begin{array}{l}\text { 1. Maintain the quality of the } \\
\text { products sold and maintain the } \\
\text { quality of service and develop } \\
\text { social media-based promotions. }\end{array}$ & $\begin{array}{l}\text { 1. Start using price tagging and } \\
\text { gradually reduce debt owed to } \\
\text { buyers while maintaining good } \\
\text { relations with them. }\end{array}$ \\
\hline Threat & $\begin{array}{l}\text { STRATEGY ST } \\
\end{array}$ & STRATEGY WT \\
\hline $\begin{array}{l}\text { 1. Tight competition (the } \\
\text { proliferation of mobile vegetable } \\
\text { traders) } \\
\text { 2. The home of the mobile } \\
\text { vegetable traders is far from the } \\
\text { location where they sell their } \\
\text { products, so they have to hunt for } \\
\text { time each day so that customers } \\
\text { do not move or buy from other } \\
\text { traders. } \\
\text { 3. Customers who are decreasing } \\
\text { from time to time since the } \\
\text { increasing number of vegetable } \\
\text { traders around. }\end{array}$ & $\begin{array}{l}\text { 1. Provide the maximum possible } \\
\text { service for consumers both in terms } \\
\text { of product quality and timeliness at } \\
\text { trading locations. }\end{array}$ & $\begin{array}{l}\text { 1. Improve the quality of } \\
\text { packing, labeling, } \\
\text { Reducing sales by providing } \\
\text { debts and trying to be on time to } \\
\text { make sales at trading locations. }\end{array}$ \\
\hline
\end{tabular}

The SWOT matrix is a tool used to measure the strategic factors of mobile vegetable traders in Sukorambi Jember District. This matrix can clearly describe how the external opportunities and threats are. This matrix can generate alternative possible cell strategies. 


\section{INTERPRETATION}

After discussing the IFAS matrix, EFAS, Cartesian diagram and SWOT matrix, the following will describe in detail the alternative strategies that can be implemented by mobile vegetable traders in Sukorambi Jember District.

This strategy is a combination of internal factors (Strength) and external factors (Opportunity), this strategy is made based on utilizing all strengths to seize and take advantage of the greatest possible opportunities by the vegetable traders in Sukorambi District. The SO strategy being pursued is to maintain the quality of the products sold and to maintain the quality of service and to develop social media-based promotions. The products that are sold by mobile vegetable traders in Sukorambi Jember District are varied or varied because they generally take or buy these vegetables at the Tanjung Jember market where in this market traders can easily get a wide variety of fresh vegetables from 01.00 in the morning until $05.00 \mathrm{am}$. Traders' habits of providing good service for their customers will create customer loyalty that can ensure that customers do not move to other traders, gratuities for loyal customers are also done to provide satisfaction to loyal customers so that a better relationship will be created between traders and buyers, the gratuity here can be interpreted as an annual bonus which is usually given during the fasting month or when approaching the Eid al-Fitr. Traders have also begun to understand the ease and usefulness of information technology by creating a WA status related to the products they sell so that customers who have stored the number of the merchant will know about the product that has been made status or promoted directly by sending it to the customer's WA number itself. The point is to maintain good relations and keep customer numbers, so it will support the ease of marketing the vegetables sold by the vegetable traders themselves.

This strategy is a combination of internal factors (Strength) and external factors (Threat), this strategy uses the strengths of mobile vegetable traders in Sukorambi Jember District to overcome all existing threats. ST's strategy is to provide the maximum possible service for consumers both in terms of product quality and timeliness at trading locations. This means that vegetable traders in Sukormabi Jember District have advantages in terms of product quality and the variety of vegetables being sold, technological advances can also be used to overcome the problem where the distance between the merchant's house and the selling location is quite far, so it is better to use good communication media through the WhatsApp application and so on so that sellers can inform you about what time they can arrive at the selling location because customers who are loyal and there is already a good relationship between sellers and buyers are usually willing to wait for vegetable traders who have become customers, the most important thing is not to be late accordingly what has been communicated at the beginning regarding that time and the traders must be on time in the sense that the buyer already knows that trader A, for example, if at 7.00 WIB usually arrives at their location.

This strategy is a combination of internal factors (Weakness) and external factors (Opportunity), this strategy is applied based on the use of existing opportunities by reducing the weaknesses of traders. The WO strategy adopted by mobile vegetable traders in the Sukorambi Jember sub-district is to start using price tags and gradually reduce debts to buyers while maintaining good relations with them. Mobile vegetable traders in Sukorambi District should take advantage of good relationships with their customers and always strive to provide the best service for their consumers, for example by providing price labeling for products being sold so that when many buyers do not make mistakes in determining prices and difficulty calculating for the traders themselves, then as much as possible 
maybe avoid sales by sending merchandise to buyers this can only be done for customers who can be trusted only in quotes never forget their debt and always pay it off.

This strategy is a combination of internal factors (Weakness) and external factors (Threat). This strategy is based on defensive activities and tries to avoid possible external threats to reduce trader weaknesses. The WT strategy adopted by mobile vegetable traders in Sukorambi Jember sub-district is to improve the quality of packing, labeling, reduce sales by providing debts and trying to be on time in making sales at trading locations. Customers certainly need good service and the quality of the products purchased must also be good, customers need convenience. From the things that have been mentioned, traders should avoid things that are not desired by customers, for example bad products, not quality, bad service (songong traders), not on time so customers wait too long and in the end customers turn to vegetable traders. another.

\section{CONCLUSION}

From the IFAS results, the strength and weakness factors have a total score of 2.95. If the total score is below 2.5 it indicates that the trader is weak internally. Meanwhile, a total value above 2.5 indicates a strong internal potential. From this it can be judged that the internal potential of mobile vegetable traders in the Sukorambi Jember sub-district is strong.

From the EFAS results, the opportunity and threat factors have a score of 3.59. Because the total score is close to 4.0 , this means that it indicates that the mobile vegetable traders in Sukorambi Jember sub-district respond to opportunities in an extraordinary way and avoid threats in the market or where they are selling.

The total value of Strength is 2.24, skill 0.71 , opportunity 2.18 , threat 1.41 . It can be explained that the mobile vegetable traders in Sukorambi Jember District are in quadrant I, namely Aggressive (Growth
Oriented Strategy) where this power is a very profitable situation. These traders have opportunities and strengths so they can take advantage of the opportunities that exist. This strategy that must be implemented in this condition is to support aggressive growth policies.

The SO strategy being pursued is to maintain the quality of the products sold and to maintain the quality of service and to develop social media-based promotions.

The ST strategy is to provide the maximum possible service for consumers both in terms of product quality and timeliness at trading locations.

The WO strategy adopted by mobile vegetable traders in the Sukorambi Jember sub-district is to start using price tags and gradually reduce debts to buyers while maintaining good relations with them.

The WT strategy adopted by mobile vegetable traders in Sukorambi Jember subdistrict is to improve the quality of packing, labeling, reduce sales by providing debts and trying to be on time in making sales at trading locations.

\section{IMPLICATIONS}

Efforts are made to improve the quality of the products sold with a more appropriate form of packing, labeling the price on each package of merchandise.

Reduce giving debts to customers who have never been unsportsmanlike in paying off their debts in the sense that they have never kept promises, do this in a polite way so as not to hurt the customer.

To avoid increasingly fierce competition and reduced customers, mobile vegetable traders in Sukorambi Jember District can improve service quality, one of which is being able to come on time to the selling location, which in essence requires the sacrifice of time where of course the traders have to leave earlier, thus It is hoped that the customer will not move to another merchant.

\section{REFERENCES}

Assauri, Sofjan. 2013. Manajemen 
Pemasaran. Jakarta : Rajawali Pers. BPS. 2019. https://www.bps.go.id/. Diakses 5 Maret 2020.

David dan Fred R. 2006. Manajemen Strategi: konsep-konsep. Jakarta: INDEKS Kelompok Gramedia.

Freddy, Rangkuti. 2003. Analisis SWOT Teknik Membedah Kasus Bisnis. Jakarta: PT. Gramedia Pustaka Utama.

KBBI. 2020. Kamus Besar Bahasa Indonesia (KBBI). Online Available
At https://kbbi.kemdikbud.go.id/ Diakses 3 Maret 2020.

Kotler, Philip. 2009. Manajemen Pemasaran. Edisi 13 Jilid 1. Edisi Terjemahan Oleh Bob Sabran. Jakarta : Erlangga.

Todaro, Michael P. 2000. Ekonomi Untuk Negara Berkembang. Edisi 3. Cetakan 1. Jakarta: PT Bumi Aksara. 